\title{
A Study on Employee Retention as a Tool for Improving Organizational Effectiveness
}

\author{
Nethravathi P. S. ${ }^{1}$, P. S. Aithal ${ }^{2}$, Gayathri Babu J. ${ }^{3}$, Sonia Soans ${ }^{4}$, \& Honey Jayaraj ${ }^{5}$ \\ ${ }^{1}$ Professor, College of Computer and Information Sciences, Srinivas University, Mangalore \\ Orcid ID:0000-0001-5447-8673; Email: nethrakumar590@gmail.com \\ ${ }^{2}$ Professor, College of Computer and Information Sciences, Srinivas University, Mangalore \\ Orcid ID:0000-0002-4691-8736; Email: psaithal@ gmail.com \\ ${ }^{3}$ HOD, Department of MBA, Shree Devi Institute of Technology, Mangalore \\ ${ }^{3}$ Email: gaai3bj378@gmail.com \\ ${ }^{4}$ Lecturer, University of Technology and Applied Sciences, Sultanate of Oman \\ Orcid ID:0000-0002-4964-1197; Email: sonia.soans1234@ gmail.com \\ ${ }^{5}$ Shree Devi Institute of Technology, Email: honeyjayarajp@gmail.com
}

Area/Section: Management.

Type of the Paper: Research Analysis.

Type of Review: Peer Reviewed as per $|\mathrm{C}| \mathrm{O}|\mathrm{P}| \mathrm{E} \mid$ guidance.

Indexed in: OpenAIRE.

DOI: https://doi.org/10.5281/zenodo.5526251

Google Scholar Citation: $\underline{\text { IJMTS }}$

\section{How to Cite this Paper:}

Nethravathi, P. S., Aithal, P. S., Gayathri Babu, J., Sonia Soans, \& Honey Jayaraj (2021).

A Study on Employee Retention as a Tool for Improving Organizational Effectiveness. International Journal of Management, Technology, and Social Sciences (IJMTS), 6(2), 121-132. DOI: https://doi.org/10.5281/zenodo.5526251

International Journal of Management, Technology, and Social Sciences (IJMTS)

A Refereed International Journal of Srinivas University, India.

CrossRef DOI: https://doi.org/10.47992/IJMTS.2581.6012.0161

(C) With Author.

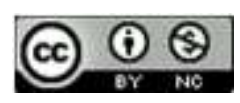

This work is licensed under a Creative Commons Attribution-Non-Commercial 4.0 International License subject to proper citation to the publication source of the work.

Disclaimer: The scholarly papers as reviewed and published by the Srinivas Publications (S.P.), India are the views and opinions of their respective authors and are not the views or opinions of the SP. The SP disclaims of any harm or loss caused due to the published content to any party. 


\title{
A Study on Employee Retention as a Tool for Improving Organizational Effectiveness
}

\author{
Nethravathi P. S. ${ }^{1}$, P. S. Aithal ${ }^{2}$, Gayathri Babu J. ${ }^{3}$, Sonia Soans ${ }^{4}$, \& Honey Jayaraj ${ }^{5}$ \\ ${ }^{1}$ Professor, College of Computer and Information Sciences, Srinivas University, Mangalore \\ Orcid ID:0000-0001-5447-8673; Email: nethrakumar590@gmail.com \\ ${ }^{2}$ Professor, College of Computer and Information Sciences, Srinivas University, Mangalore \\ Orcid ID:0000-0002-4691-8736; Email: psaithal@ gmail.com \\ ${ }^{3}$ HOD, Department of MBA, Shree Devi Institute of Technology, Mangalore \\ ${ }^{3}$ Email: gaai3bj378@gmail.com \\ ${ }^{4}$ Lecturer, University of Technology and Applied Sciences, Sultanate of Oman \\ Orcid ID:0000-0002-4964-1197; Email: sonia.soans1234@ gmail.com \\ ${ }^{5}$ Shree Devi Institute of Technology, Email: honeyjayarajp@ gmail.com
}

\begin{abstract}
Background/Purpose: Human sources are those who make the group of workers of a company. It's also recognized via manpower, skills, labour, employees etc. Human Resource department of a business enterprise performs human useful resource control. It entails various elements of the employment consisting of compliance with labour regulation and employment standards, management of worker benefits, and various other sports related to recruitment and choice of the employee. Worker retention is regarding the efforts with the aid of which employers try and retain the personnel in their team of workers. Retention turns into the strategies in place of the final results. Preserving the worker for long duration of time is known as retention. Retention strategies of the organization need to have the capacity to attract and hold their staff. Organizational effectiveness refers to a company's ability to achieve the goals it sets out to achieve. It's far the performance of the organization, group or an organization to fulfill its goal. Six Sigma is a methodology that makes a specialty of improving the overall efficiency of a business process.

Objective: This work is carried out at Dinesh Foods, Kannur. Dinesh foods are a subsidiary unit of Kerala Dinesh Beedi Workers Co-op Society. The objective of this study is to observe and to recognize how worker retention facilitates in growing the organizational effectiveness of Dinesh Foods. It additionally assists to investigate diverse retention techniques followed and also the employee turnover within the unit. This work investigates the worker retention is a device for increasing the organizational effectiveness.
\end{abstract}

Design/Methodology/Approach: For the purpose of study the data was collected through primary and secondary source. Questionnaire was distributed among the workers for collecting necessary data for the study, financial statement of the company to study about the financial stability of the organisation and annual report of the company.

Findings/Results: This research is done to find out whether the employee retention in the organisation helps in improving the organisational effectiveness. Varies conditions applied for the hypothesis and it can be proved that the employee retention is a tool for increasing the organisational effectiveness. Based on the analysis, findings and suggestions Dinesh Foods, Kannur can give more concentration towards retaining the employees in the organisation as it is important in any organization.

Conclusion: This study focusses on whether employee retention is a tool for improving the organisational effectiveness. It is found that the employee retention is a tool for improving organisational effectiveness and employee retention helps in increasing the productivity.

Paper Type: Case study-based Research Analysis

Keywords: Human Resource, Organizational effectiveness, Business Enterprise, Employee Retention, Financial Stability 


\section{INTRODUCTION :}

The structure of the global food processing enterprise is to be changing continuously for assembly or satisfying the customer needs and expectations [1] [2]. The purchaser inside the market will demand a wide kind of high first-rate and differentiate products. The agencies inside the industry will introduce the various innovative sales codecs for the success in industry. The supermarket, discounters, convenience store, hypermarket and grocery retailers etc. are to be the new emerged innovations in the current years [3].

Nearly 25 trillion U.S dollars made in international market [4] and most of leading international outlets are to be the US and European firms, they are the aggressive leaders with in the retail sector. The pinnacle worldwide grocery store agencies are to be contributing $30 \%$ of the whole international supermarket sales. The pinnacle 15 international supermarket groups sales account are to be extra than 30 consistent with cent of the world supermarket contribution. In 2020 the food market revenues are to be expected $\$ 3.03$ trillion and additionally their cord indicates that there's a compound annual boom rate (CAGD) of four 5\% from 2015 to 2020 . Huge increase of the world huge packed grocery store is mainly because of the growing demand from the rising economies. The India and China are expecting to show an enormous increase inside the packaged food market. The majority of the pinnacle meals processing companies are seeking to improve their brand consciousness through the numerous promotional activities. The businesses are spending a chief portion of finance for the promotional activities [5]. The Nestle and Kraft meals devices are pinnacle agencies in spending or investing closely on promotional and growing brand consciousness for helping product differentiation.

\subsection{Food industry in India:}

India is likely to overhaul China and it has all the possibility to develop the top most important diet and position in farming region. India is identified one of the most manufacturer of food. Our country is in the 5th manufacture, consume, exportation and expected growth. India is well known for food processing industry is in a rapid boom stage, it will increase the sector meals alternate in each year.

The food manufacturers presently worth for US $\$ 39.71$ billion and the enterprise, could assume to grow at US $\$ 65.4$ billion by using 2018 . The total food and grocery account reveal that the $31 \%$ of total food and grocery consumption is in India and contributing around 17 percent of manufacturing GDP, 13\% cent of Indians export and six percent of overall commercial investment. A successful business case will define the problem, all possible solutions, and provide sufficient information, including uncertainties, to decision-makers so they can determine the best course of action for the organization [6] [7]. The most common technique for auditing and analysing a company's entire strategic position and environment is the SWOC Analysis. Its goal is to advance ways for creating a firm-specific business model that best aligns an organization's resources and competencies with the demands of the environment in which it operates. [8]. Table 1 below depicts SWOT analysis of the food industry.

\subsection{Major players in Indian food processing:}

ITC Limited, Cadbury India Ltd, PepsiCo India Holdings, Nestle India, Brittanie Industries Ltd, HUL, MTR Foods Ltd, Godreg, etc.

Table 1: The SWOT Analysis of Food Industry

\begin{tabular}{|c|c|}
\hline STRENGHT & WEAKNESS \\
\hline $\begin{array}{l}\text { (1) The central government has granted agro } \\
\text { processing priority sector status due to abundant } \\
\text { raw material availability. } \\
\text { (2) A large network of manufacturing plants spread } \\
\text { across the country } \\
\text { (3) Domestic market is vast. }\end{array}$ & $\begin{array}{l}\text { (1) There is a scarcity of suitable infrastructure } \\
\text { facilities. } \\
\text { (2) Working capital requirements are higher. } \\
\text { (3) Linkages between research organisations } \\
\text { and industry are insufficiently formed. } \\
\text { (4) Raw material seasonality. } \\
\text { (5) Insufficient quality control and testing } \\
\text { techniques in accordance with international } \\
\text { standards. } \\
\text { (6) Due to a huge number of intermediaries, the } \\
\text { supply chain is inefficient }\end{array}$ \\
\hline OPPORTUNITY & THREAT \\
\hline
\end{tabular}

Nethravathi P. S., et al, (2021); www.srinivaspublication.com 
(1) A huge agricultural and material base with a lot of agro-processing possibilities.

(2) Agri-export zones (AEZs) and food parks are being stablished to provide additional incentives for the development of greenfield ventures.

(3) Changing consumption patterns and rising income levels

(4) Changing lifestyles and a favourable demographic profile

(5) Integration of recent technological advances like electronics, material science and biotechnology, among others, offers enormous potential for quick advancement.
(1) Affordability and culture

(2) Fresh-food preferences

(3) Excessive taxation

(4) Excessive packaging

\section{OBJECTIVES OF THE STUDY :}

(1) To analyse whether employee retention is a tool for improving organisational effectiveness in Dinesh Foods, Kannur.

(2) To analyze employee benefits helps in retaining the employees in Dinesh Foods, Kannur.

(3) To study the effect of job satisfaction in retaining the employees in Dinesh Foods, Kannur.

(4) To find out whether job security is a determinant factor for retaining the employee in Dinesh Foods, Kannur.

\section{LITERATURE REVIEW :}

The success of a company is determined on the competence of its employees; if employees are retained for a long time, the company's goodwill will increase [9]. However, it is a high-quality endeavour to maintain all of the employees in a happy stage. During their investigation, the researchers discovered that the current working environment may be the most important factor in retaining their employees. If the working atmosphere is pleasant, employees are more likely to contribute to the success of their company. Employee retention is a well-known fact that goes hand in hand with work happiness. Alternative features such as flexible work, a fun and enjoyable work environment, career opportunities, recognition, and so on are important factors in retaining employees. They investigated workers' perceptions of the current system in the beverage business by taking 329 samples (Ramakrishnan $\mathrm{S}$ and Maran K. 2016) [10].

Organizational way of life and employee assurance is the gauging tool for employee retaining. Authors performed by taking 200 trails from Coimbatore industry and automobile spare parts. They found that if the business culture is very good then, the employees will be motivated and loyal towards the company. The firm's way of life is very important in Indian context and the it will bring their personnel more committed. If obligations get doubled then, performance also reaches too high. The employees could be influenced more of their self-esteem, respect, job design and other retention factors (Anita $\mathbf{J}$ and Farida Begum N. 2016) [11].

Authors say that employee retention has a good association between remuneration aspects and corporate culture. They discovered that compensation coverage and organisational culture are the most powerful determinants of employee retention. They also mentioned that, there is a positive relation between these two factors in retaining the people in the workplace. It is a big challenge for an organization to preserve key abilities. Employees wage negotiations and rewards allows to preserve all range of employees. (Maqsood Haider et al. 2015) [12].

The principal factors that have an effect on the employee retention in medical area in India, authors collected around 150 datasets from three unique companies in Chennai. It is observed that the companies must create a good atmosphere to make people stay with them. HR must plan the future career path of their own working people by promotions and other facilities. HR should look at future retain dedicated people by improving job satisfaction and help continuous and constant help to encourage personal (Latha Suresh \& R. Krisahnaraj 2015) [13].

The authors conducted research with $10 \mathrm{MNCs}$ with 10 samples from each. By random sampling method they picked the respondents. They inspected the effect of three R's (Respect, Recognition and Rewards) by grading the satisfaction of the respondents. The employees were happy with the implementation of 3 R's and are secure closer to the policy implantation. Some activities like yoga and 
other leisure activities initiated by the management to refreshen them (Sultana Nazia and Bushra Begum 2013) [14].

The employees' emotional perception of employees was analyzed. Retention is not possible in a single plan but it should constant best plan for natural requirement. They said that employee retention is supportive for best performance and growth in production of the product. Trusted employees contribute a lot and involve in major decision-making process with their abilities. To solve these issues, mentally employees should be happy and it helps corporates to retain them for long (Memoona et al. 2013) [15]. A study carried out on co-relation with employee involvement as an independent variable and effectiveness as a dependent variable. Involvement changed into scaled by means of empowerment, team orientation and capability development. Organisational effectiveness became measured by profitability, productiveness and market share. Outcomes showed that employee involvement definitely stimulated organisational effectiveness. An extensive evaluation of literature indicates that employee empowerment as a device has not been sufficiently studied in terms of organisational effectiveness. Even though the concept isn't new in India, it's far but to advantage maturity in comparison to that of the foreign research. Most of the research in India has focused on applications and practices instead of on its intrinsic value to the organisation. The studies have constrained to the level of job commitment and employee's job satisfaction (Das Simanchala, Tapas Ranjan 2017) [16].

Another study on sought to examine the relationship among knowledge sharing, organisational mastering and organisational effectiveness. Organisational effectiveness was defined as the outcome of managerial effectiveness and operational overall performance. It was hypothesized that organisational learning and knowledge sharing, positively affect organizational effectiveness. (Yang 2007) [17].

To attain the organisational goal with a purpose to bring about organisational effectiveness, it is very important to have a good mind set, feeling of willingness to work with dedication. This is a crucial tool for evaluating people involvement. If the employees are more involved and interested, it leads them to empower in the work place. Many works proved that, where employee involvement is more effective, they were given significance for their works. This shows that management must give some power to its employees in making decision and apply whenever required. This can improve their participation level and they would turn out to be actively engaged resulting employee retentions (Eileen M. Traut 2012) [18].

To find the relationship between the employee retention and other various factors, the data collected and the data has categorical variables that can be summarized as a series of counts and usually listed in a tabular format known as a contingency table [19]. To find out the association between the rows and columns, chi-square test will be utilized.

It is realized from the above survey that; a statistical tool helps to determine the differences between the training collections in the proportions of the risk factor of interest. Chi-square test and the logic of hypothesis testing were utilized [20] [21].

\section{RESEARCH-METHODOLOGY :}

Main goal of this work is to find out whether employee retention is a tool for improving organisational effectiveness. A statistical tool, Chi - square Analysis is applied for the hypothesis selected listed below:

\subsection{Hypothesis-1}

H0 - No substantial association among organisational effectiveness by employee retention and increase in productivity by employee retention in Dinesh Foods, Kannur.

H1 - There is a significant relationship between organisational effectiveness by employee retention to improve employee retention in Dinesh Foods, Kannur.

By testing the above hypothesis, it can be proved that the employee retention is a tool for increasing the organisational effectiveness or not. The below given hypothesis would support the study.

\subsection{Hypothesis-2}

$\mathrm{H} 0$ - No substantial association among employee retention and the benefits provided to employees in Dinesh foods, Kannur.

$\mathrm{H} 1$ - one can find relationship with employee retention and the benefits provided to employees in Dinesh foods, Kannur.

\subsection{Hypothesis-3}

Nethravathi P. S., et al, (2021); www.srinivaspublication.com 
H0 - No relationship with the satisfaction level of various factors and employee retention in Dinesh Foods, Kannur.

$\mathrm{H} 1$ - There is relationship with the satisfaction level of various factors and employee retention in Dinesh Foods, Kannur.

\section{ANALYSIS \& INTERPRETATION :}

\subsection{Hypothesis -1}

Correlation Coefficient Analysis is applied for the above-mentioned factors of Hypothesis- 1 and found the following value.

Table 2: Correlation between the employee retention with organisational effectiveness and increase in productivity.

\begin{tabular}{|c|c|c|c|}
\hline Statement & Parameters & $\begin{array}{c}\text { Employee retention } \\
\text { improves the } \\
\text { organisational } \\
\text { effectiveness }\end{array}$ & $\begin{array}{c}\text { Employee } \\
\text { retention } \\
\text { increases the } \\
\text { productivity }\end{array}$ \\
\hline $\begin{array}{c}\text { Employee retention improves } \\
\text { the organisational }\end{array}$ & Pearson Correlation & 1 & $.764 "$ \\
effectiveness & (PC) & 40 & .000 \\
Sig. (2-tailed) & $\mathrm{N}$ & $.764 \%$ & 40 \\
$\begin{array}{c}\text { Employee retention increases } \\
\text { the productivity }\end{array}$ & $\mathrm{PC}$ & .000 & 1 \\
\hline
\end{tabular}

\section{Interpretation}

Correlation significant is seen in 0.01 level.

From the analysis, the Pearson Correlation Coefficient (PCC) got is 0.764 . It is in between 0 and 1 . After the analysis if we got a value which is between 0 and 1 ; it indicates that the variables are positively correlated. In this analysis the coefficient is 0.764 which indicates that the variables are correlated positively. If the variables are positively correlated then, relationship exists and improved production among organizational effectiveness and employee retention. So, it is proved that the employee retention is a tool for improving organisational effectiveness.

\subsection{Hypothesis-2}

After applying correlation for the hypothesis- 2 mentioned above, the following results obtained and listed in the following Table 3.

Table 3: Showing the correlation between employee retention and the benefits provided

\begin{tabular}{|c|c|c|c|}
\hline Statement & Parameters & $\begin{array}{l}\text { Employee } \\
\text { retention }\end{array}$ & $\begin{array}{l}\text { Employee } \\
\text { benefits }\end{array}$ \\
\hline Employee retention & $\begin{array}{c}\text { Pearson Correlation } \\
\text { Sig. (2-tailed) } \\
\text { N } \\
\text { PC } \\
\text { Sig. (2-tailed) } \\
\text { N }\end{array}$ & $\begin{array}{c}1 \\
40 \\
.577 \\
.000 \\
40 \\
\end{array}$ & $\begin{array}{c}.577 " \\
.000 \\
40 \\
1 \\
40 \\
\end{array}$ \\
\hline
\end{tabular}

\section{Interpretation}

From the analysis, the Pearson Correlation Coefficient got is 0.577. It is in between 0 and 1 . After the analysis if we got a value which is between 0 and 1, it indicates that the variables are positively correlated. If the coefficient is of negative then the two variables are negatively correlated. Positive correlation means if one variable is increasing then the other also will increase and negative correlation means one variable will get increase while the other variable will get decrease. In this analysis the coefficient is 0.577 ; it indicates that the variables are positively correlated and there is relationship between the variables under study. Here employee retention and employee benefit have a significant relationship between each other as the coefficient is positively correlated. 


\subsection{Hypothesis-3}

For the final hypothesis-3, the Chi - Square Analysis are performed. The result from this test is as shown below in Table 4.

Note: The factors that are considered are working environment, company's rules and regulations, job in the organisation, working hours and refreshment time, morale among the coworkers, job security and welfare measures.

\subsection{Sub-hypothesis 1}

$\mathrm{H}_{0}$ - No association between satisfaction level of working environment

$\mathrm{H}_{1}$ - There is relationship between the satisfaction level of working envt.,

Table 4: Chi-square analysis between the working environment and employee retention

\begin{tabular}{|c|c|c|c|}
\hline Parameters & Value & D $_{\mathbf{f}}$ & $\begin{array}{c}\text { Asymp. } \\
\text { Sig. (2-sided) }\end{array}$ \\
\hline Pearson Chi-Square & $31.837^{\mathrm{a}}$ & 2 & .000 \\
Likelihood Ratio & 37.386 & 2 & .000 \\
Linear-by-Linear Association & 22.877 & 1 & .000 \\
N of Valid Cases & 40 & & \\
\hline
\end{tabular}

\section{Interpretation}

a. 2 cells $(33.3 \%)<$ expected 5. The min. predictable count is 2.70 .

By doing the analysis, the value obtained is 0.000 ; which is less than the standard value. The standard value is 0.05 . Hence the null hypothesis should reject and alternative hypothesis must accept. It is proved that there is a significant relationship between the satisfaction level of working environment and employee retention in Dinesh Foods.

\subsection{Sub hypothesis-2}

$\mathrm{H}_{0}$ - There is no significant relationship between the satisfaction level of rules and regulations in Dinesh Foods and employee retention in Dinesh Foods, Kannur.

$\mathrm{H}_{1}$ - There is a significant relationship between the satisfaction level of rules and regulations in Dinesh Foods and employee retention in Dinesh Foods, Kannur.

Table 5: Chi square analysis between the rules and regulations and employee retention

\begin{tabular}{|c|c|c|c|}
\hline Parameters & Value & $\mathbf{D}_{\mathbf{f}}$ & $\begin{array}{c}\text { Asymp. } \\
\text { Sig. (2-sided) }\end{array}$ \\
\hline Pearson Chi-Square & $15.510^{\mathrm{a}}$ & 2 & .000 \\
Likelihood Ratio & 20.187 & 2 & .000 \\
Linear-by-Linear Association & 13.186 & 1 & .000 \\
N of Valid Cases & 40 & & \\
\hline
\end{tabular}

\section{Interpretation}

a. 2 cells $(33.3 \%)<$ than expected 5. Min predictable count $=60$.

By doing the Chi-Square analysis, the value obtained is 0.000 . The standard value is 0.05 . As a result, the resulted value is lower to standard value. The null hypothesis is refused, other hypothesis is accepted when obtained value is less than the standard one. We will accept the alternative hypothesis and reject the null hypothesis in this situation because the obtained value is less. We will accept the other hypothesis and discard the null hypothesis. The alternative hypothesis is there is significant relationship between the satisfaction level of rules and regulation in Dinesh Foods and employee retention in Dinesh Foods. So, it is proving that the satisfaction level of employees in rules and regulation of the company can affect the retention of the employee in the organisation.

$\mathrm{H}_{0}$ - There is no significant association among the satisfaction level of job in Dinesh Foods and employee retention in Dinesh Foods, Kannur.

$\mathrm{H}_{1}$ - We have seen relationship here. 
Table 6: Chi square analysis between the job and employee retention

\begin{tabular}{|c|c|c|c|c|c|}
\hline Parameters & Value & $d_{f}$ & $\begin{array}{l}\text { Asymp. Sig. } \\
\text { (2-sided) }\end{array}$ & $\begin{array}{l}\text { Exact Sig. } \\
\text { (2-sided) }\end{array}$ & $\begin{array}{l}\text { Exact Sig. } \\
\text { (1-sided) }\end{array}$ \\
\hline $\begin{array}{l}\text { Pearson Chi-Square } \\
\text { Continuity Correction } \\
\text { Likelihood Ratio } \\
\text { Fisher's Exact Test } \\
\text { Linear-by-Linear } \\
\text { Association } \\
\text { N of Valid Cases }\end{array}$ & $\begin{array}{l}14.026^{\mathrm{a}} \\
11.549 \\
18.553 \\
13.675 \\
40\end{array}$ & $\begin{array}{l}1 \\
1 \\
1 \\
1\end{array}$ & $\begin{array}{l}.000 \\
.001 \\
.000\end{array}$ & .000 & .000 \\
\hline
\end{tabular}

\section{Interpretation}

a. 0 cells $(0.0 \%)$ have count $<$ expected 5. Min. expected $=5.40$.

b. Calculated for a $2 \times 2$ table.

By doing the Chi-Square analysis, the value obtained is 0.001 . The normal value is 0.05 . Hence the obtained value is lower than the standard one. When the obtained value is lesser than the standard then the null hypothesis is rejected and alternative hypothesis is accepted. In this case as the obtained value is less than the standard, so we will accept the alternative hypothesis and will reject the null hypothesis. There is substantial link among the satisfaction level of job in Dinesh Foods and employee retention in Dinesh Foods. So, it is demonstrated that the satisfaction level of employees with the job that they are performing in the company can affect the retention of the employee in the organisation.

$\mathrm{H}_{0}$ - No substantial association between the satisfaction level of working hour and refreshment time $\mathrm{H}_{1}$-Satisfaction level of working hour and refreshment time relation is found.

Table 7: Chi square analysis between the working hour and refreshment time and employee retention in Dinesh Food, Kannur

\begin{tabular}{|c|c|c|c|}
\hline Parameter & Value & $\mathbf{D}_{\mathbf{f}}$ & Asymp. Sig. (2-sided) \\
\hline Pearson Chi-Square & $23.193^{\mathrm{a}}$ & 2 & .000 \\
Likelihood Ratio & 28.272 & 2 & .000 \\
Linear-by-Linear Association & 17.824 & 1 & .000 \\
N of Valid Cases & 40 & & \\
\hline
\end{tabular}

\section{Interpretation}

a. 2 cells $(33.3 \%)<$ expected 5 . Min expected $=3.30$.

By doing the Chi-Square analysis, the value obtained is 0.000 . The standard value is 0.05 . Hence the obtained value is low. When the obtained value is lower compared to standard value, then the null hypothesis is rejected and alternative hypothesis is accepted. In this case as the obtained value is less than the standard, we will accept alternative hypothesis and refuse the null hypothesis. Alternatively, satisfaction level of working hours over refreshment is found. So, it is proved that the satisfaction level of employees regarding the working hours and refreshment time in the company effect the retention of the employee in the organization.

$\mathrm{H}_{0}$ There is no relationship with coworkers in Dinesh Foods and employee retention in Dinesh Foods, Kannur.

$\mathrm{H}_{1}$ - Relationship found here.

Table 8: Showing the Chi square analysis between the relationship with coworkers and employee retention.

\begin{tabular}{|l|c|c|c|}
\hline Parameters & Value & D $_{\mathbf{f}}$ & Asymp. Sig. (2-sided) \\
\hline Pearson Chi-Square & $23.193^{\mathrm{a}}$ & 2 & .000 \\
Likelihood Ratio & 28.272 & 2 & .000 \\
Linear-by-Linear Association & 2.531 & 1 & .112 \\
N of Valid Cases & 40 & & \\
\hline
\end{tabular}

\section{Interpretation}

a. 2 cells $(33.3 \%)$ have counts less than expected 5 . The minimum expected count is 1.80 .

By doing the Chi - The value of square analysis, obtained is 0.112 . The standard value is 0.05 . Hence obtained value greater than standard value. When the obtained value is more than the standard then the 
null hypothesis is accepted and alternative hypothesis is rejected. In this case as the obtained value is more, one can accept null and reject alternative one. The null hypothesis is there is no significant relationship between the satisfaction level of association with the coworkers in Dinesh Foods and employee retention in Dinesh Food. So, it is proved that the satisfaction level of employees regarding the relationship between the coworkers in the company have no impact in the retention of the employee of an organization.

\section{Sub hypothesis-6}

$\mathrm{H}_{0}$-Satisfaction level of job security is not there.

$\mathrm{H}_{1}$-Substantial relationship among the satisfaction level of job security at Dinesh Foods and employee retention in Dinesh Foods, Kannur.

Table 9: Chi square analysis between the job security and employee retention

\begin{tabular}{|c|c|c|c|c|c|}
\hline Parameters & Value & $d_{f}$ & $\begin{array}{l}\text { Asymp. Sig. } \\
\text { (2-sided) }\end{array}$ & $\begin{array}{l}\text { Exact Sig. } \\
\text { (2-sided) }\end{array}$ & $\begin{array}{l}\text { Exact Sig.(1- } \\
\text { sided) }\end{array}$ \\
\hline $\begin{array}{l}\text { Pearson Chi-Square } \\
\text { Continuity Correction } \\
\text { Likelihood Ratio } \\
\text { Fisher's Exact Test } \\
\text { Linear-by-Linear } \\
\text { Association } \\
\text { N of Valid Cases }\end{array}$ & $\begin{array}{l}20.952^{\mathrm{a}} \\
17.898 \\
25.955 \\
\\
20.429 \\
40\end{array}$ & $\begin{array}{l}1 \\
1 \\
1\end{array}$ & $\begin{array}{l}.000 \\
.001 \\
.000 \\
.000\end{array}$ & .000 & .000 \\
\hline
\end{tabular}

a. 0 cells $(0.0 \%)$ have counts less than expected 5. Minimum expected count is 5.40.

\section{Interpretation}

b. Performed for $2 \times 2$ table

By doing the Chi-Square analysis, the value obtained is 0.000 . The standard value is 0.05 . Hence, obtained count is lower than the standard value. When the obtained value is less than the standard then the null hypothesis is rejected and alternative hypothesis is acknowledged. In this case as the obtained value is less than the standard value, we will accept the alternative hypothesis and will reject the null hypothesis. The alternative hypothesis is there is a link between the satisfaction level of job security at Dinesh Foods and employee retention in Dinesh Foods. So, it is proving that the satisfaction level of employees regarding the job security in the company effect the retention of the employee in the organisation.

\section{Sub hypothesis-7}

$\mathrm{H}_{0}$-Satisfaction level of welfare measures not found.

$\mathrm{H}_{1}-$ Association is found with satisfaction level of welfare measures.

Table 10: Chi square analysis between the welfare measures and employee retention

\begin{tabular}{|c|c|c|c|c|c|}
\hline Parameters & Value & $\mathbf{d}_{\mathbf{f}}$ & $\begin{array}{l}\text { Asymp. Sig. } \\
\text { (2-sided) }\end{array}$ & $\begin{array}{l}\text { Exact Sig. } \\
\text { (2-sided) }\end{array}$ & $\begin{array}{l}\text { Exact Sig. (1- } \\
\text { sided) }\end{array}$ \\
\hline $\begin{array}{l}\text { Pearson Chi-Square } \\
\text { Continuity Correction } \\
\text { Likelihood Ratio } \\
\text { Fisher's Exact Test } \\
\text { Linear-by-Linear } \\
\text { Association } \\
\mathrm{N} \text { of Valid Cases }\end{array}$ & $\begin{array}{l}8.254^{\mathrm{a}} \\
6.273 \\
11.773 \\
8.048 \\
40\end{array}$ & $\begin{array}{l}1 \\
1 \\
1\end{array}$ & $\begin{array}{l}.004 \\
.012 \\
.001 \\
\\
.005\end{array}$ & .004 & .003 \\
\hline
\end{tabular}

a. 1 cell $(25.0 \%)<$ expected 5. Expected is 3.90 .

b. Computed only for a $2 \times 2$ table

\section{Interpretation}

By doing the Chi - Square analysis, the value obtained is 0.005 . The standard value is 0.05 . Hence the attained value is less than the normal value. When the obtained value is less than the standard then the null hypothesis is excluded and alternative hypothesis is accepted. In this case as we received low value, alternative hypothesis is accepted and will reject the null hypothesis. The alternative hypothesis is there is a significant association among satisfaction level of welfare measures provided to the employees in 
Dinesh Foods and employee retention in Dinesh Foods. So, it is proved that the satisfaction level of employees regarding the job security in the company effect the retention of the employee in the organization.

\section{RECOMMENDATIONS AND CONCLUSION :}

Most of the workers in the organisation is female. So, there are concentrating to empower the women in the society. The nature of the employment of workers is permanent. Majority of the respondent is of the opinion that the employee retention helps in improving the organisational effectiveness. Organization give continues attention towards the incentives and perks offered to the employees. Majority of the respondent is of the opinion that the organisation encourages them to take part in training programs that improves the skills and competencies and also agree that the training program conducted always helps in career development.

- Most respondents have the opinion that the organisation gives appropriate recognition and reward for their performance.

- The respondents agree that there is employee retention in the organisation.

- The work load depends upon the seasonal demand for the product.

- The basic facility provide are very good in the opinion of the employees but every unit does not have canteen facility for their refreshment.

- The organisation provides various benefits like ESI, PF, Gratuity, Bonus, Incentives, Overtime pay and extra payment for the more units produced.

- Majority of the respondents thinks that implementation of three R's can increase the rate of employment retention in the organisation.

- The respondents strongly agree that management support employees when they are tackled with any problem and also in balancing their work life along with their personal life.

- Organisation always approaches the employees in an honorific way and also employees can communicate with the top-level authority without any barriers.

- Employees are not included in the decision-making process.

- Employee retention has an important role in increase in the productivity. As if the employees are working for many years continuously, they become expert in the job and can perform better.

- The employees are very well satisfied with the working environment, rules and regulation of the organisation, job, working hours and refreshment time, morale in the organisation, job security and as well as welfare measures provided to the employees.

- The employees retain in the organisation till the retirement. Because they receive many benefits. As this is a subsidiary of co-operative society, they receive all the benefits received by the employees of cooperative society.

- The retirement age is 58 years.

- Employees are mostly attracted to the benefits provided and job security.

- The employee retention is a tool for improving organisational effectiveness and also employee benefit helps in employee retention.

- Various satisfaction factors have studied and all the factors other than the morale with the coworkers have significant relationship with the employer retention.

Retention of employees becoming very important for any organization. Employees or human resource are the important asset of any organization. Retaining the same employee for more years is important because the experienced one can perform better, the organisation can reduce hiring cost, high potential can be maintained etc. Employees in the today's world are different. Successful organisation realizes that an effective employee retention plan will help the organisation in sustaining their leadership and growth in the market place.

In this work it is found that the employee retention is a tool for improving organisational effectiveness. Employee retention helps in increasing the productivity as well. Organisational effectiveness is how effective an organisation is in achieving its objective. Increasing the productivity will be an objective of the organisation. Employee benefit will help in retaining the employees in the organisation. The various factor's satisfaction level also helps in retaining the employees. So, employee retention is very much important in every organisation for achieving its objective, which will ultimately lead to improving organisational effectiveness. 


\section{SUGGESTIONS :}

The company should take initiative to improve the general working condition, welfare and recreational facilities because they are the hygienic factor whose absence will demotivate the employees.

The company should make arrangement for a forum where the employees can express their opinion / suggestions which will help the organisation to understand the problem of the employees and can take necessary decisions.

Canteen facility should be making available in all the units or at least any refreshment arrangements.

Representative of employees should involve in the decision-making process. They should give chance to participate in taking decisions regarding the problems they are facing.

There should not have any barriers for the communication with the top-level management. There should be a proper hierarchy for the communication and it should be communicated to the employees.

The supervisor should make sure that the work load in the organisation is divided properly and all the employees are engaged.

The employees should provide with more monitory benefits for the betterment of the performance.

Effective training program should conduct to make the employees up to date with the technological advancement and to increase the skill and performance.

\section{REFERENCES :}

[1] Survey on Retail market worldwide - Statistics \&amp; Facts, conducted by Statisa Research Development, 2021, https://www.statista.com/topics/5922/retail-market-worldwide.

[2]. Brody, A. L., \& Lord, J. B. (Eds.). (2007). Developing new food products for a changing marketplace. CRC Press.

[3] Jaw, B. S., \& Liu, W. (2004). Towards an integrative framework of strategic international human resource control: The case of Taiwanese subsidiaries in the People's Republic of China. The International Journal of Human Resource Management, 15(4-5), 705-729.

[4] Vision, S., \& Plan, A. (2005). Published by Rabo India Finance Pvt. Ltd. For Ministry of Food Processing Industries in India.

[5] Deckard, G. J., Borkowski, N., Diaz, D., Sanchez, C., \& Boisette, S. A. (2010). Improving timeliness and efficiency in the referral process for safety net providers: application of the Lean Six Sigma methodology. The Journal of ambulatory care management, 33(2), 124-130.

[6] Aithal, P. S. (2017). An effective method of developing business case studies based on company analysis. International Journal of Engineering Research and Modern Education (IJERME), 2(1), 16-27.

[7] Ramnarayan, S., \& Gupta, N. (2011). Introduction to organization development. Organization Development: Accelerating Learning and Transformation, 1-22.

[8] Aithal, P. S., \& Kumar, P. M. (2015). Applying SWOC analysis to an institution of higher education. International Journal of Management, IT and Engineering, 5(7), 231-247.

[9] Rampersad, H. K. (2005). Total performance scorecard: the way to personal integrity and organizational effectiveness. Measuring Business Excellence.

[10] Ramakrishnan, S \& Maran. (2016). A study on employees' perception on retention strategy based on present working environment in beverage industry, International Journal of Recent Scientific Research. 7(7), 12536-12540.

[11] Anitha, J. (2016). Role of Organisational Culture and Employee Commitment in Employee Retention. ASBM Journal of Management, 9(1), 1-19.

[12] Maqsood Haider, Aamir, Abdul Hamid, Hashim. (2015). A literature Analysis on the Importance of Non-Financial Rewards for Employees' Job Satisfaction. Abasyn Journal of Social Sciences, $8(2), 341-354$.

[13] Latha Suresh \& Krishnaraj, R. (2013). The principal factors that have an effect on the retention in pharmaceutical sector in India. International Journal of Pharmaceutical Sciences Review and Research, 2(1), 30-39. 
[14] Sultana Nazia \& Bushra Begum. (2013). Role of Learning Management System in Retention of Employee in BPO Industries in Chennai City, Journal of Business and Management, 14(2), 8-16.

[15] Memoona et all. (2018). Behavioural Efficiency: An Emerging Term in Management Sciences, Pakistan Economic Review, 1(1), 69-102.

[16] Das Simanchala \& Tapas Ranja. (2017). Employee Empowerment and 132organizational effectiveness: An Empirical study on Central Public Sector Enterprises in India, ITHIHAS The Journal of Indian Management, 7(4), 40-51.

[17] Jen Te Yang. (2007). Knowledge sharing: Investigating appropriate leadership roles and collaborative culture, Tourism Management, 28(2), 530-543.

[18] Trauth, E. M. (2012). The culture of an information economy: Influences and impacts in the Republic of Ireland, Springer Science \& Business Media, 1-445.

[19] Moore, D. S., \& Kirkland, S. (2007). The basic practice of statistics (Vol. 2). New York: WH Freeman.

[20] Sharma, A. K. (2005). Text book of correlations and regression. Discovery Publishing House.

[21] Kothari, C. R. (2004). Research methodology: Methods and techniques. New Age International.

$* * * * * * * * *$ 